\title{
Embriogênese somática em Agave sisalana Perrine: indução, caracterização anatômica e regeneração ${ }^{1}$
}

\author{
Fernando dos Santos Carneiro 2 , Sandra Regina de Oliveira Domingos Queiroz ${ }^{3}$, \\ Adriana Rodrigues Passos ${ }^{2}$, Marilza Neves do Nascimento ${ }^{2}$, Keylla Souza dos Santos ${ }^{2}$
}

\begin{abstract}
Somatic embryogenesis in Agave sisalana Perrine: induction, characterization and anatomical regeneration

Sisal (Agave sisalana Perrine) is used for the extraction of fibers present in their leaves, being considered the main hard fiber produced in the world. However, a decline has been observed for this crop, due to a disease caused by the soil fungus Aspergillus niger. Biotechnology, particularly tissue culture techniques, represents a viable alternative for propagating this species. Among these techniques, the somatic embryogenesis can be pointed out. Thus, this study aimed to characterize the in vitro morphogenesis, during somatic embryogenesis, in $A$. sisalana Perrine. In all experiments, bulblets were used as explants and also $1 / 2 \mathrm{MS}$ medium plus sucrose $\left(30.0 \mathrm{~g} \mathrm{~L}^{-1}\right)$, solidified with agar $\left(7.0 \mathrm{~g} \mathrm{~L}^{-1}\right)$ supplemented with different concentrations of auxin and cytokinin. The explants formed callus with compact and semi-compact aspects, pointing out the embryogenic cells converted into somatic embryos with the use of 2,4-D and BAP. The anatomic analyzes showed embryos in globular and torpedo stages and no connection with the mother callus.
\end{abstract}

KEY-WORDS: Sisal; micropropagation; fiber.

\section{INTRODUÇÃO}

O sisal (Agave sisalana Perrine) é uma espécie eminentemente tropical, que vegeta, naturalmente, em regiões semiáridas, apresentando-se como resistente à seca e com grande potencial para uso em regiões com baixa pluviosidade. Sua principal utilização consiste na extração das fibras contidas em suas folhas, dando origem à principal fibra dura produzida no mundo, contribuindo com mais da metade da produção comercial de todas as fibras desse tipo (Embrapa 2010).

Atualmente, tem-se confirmado um declínio contínuo dessa cultura, devido, principalmente, à

\section{RESUMO}

O sisal (Agave sisalana Perrine) é utilizado para a extração das fibras contidas em suas folhas, sendo a principal fibra dura produzida no mundo. Entretanto, tem sido observado um declínio dessa cultura, devido a uma doença causada pelo fungo de solo Aspergilus niger. A biotecnologia, em especial as técnicas de cultura de tecidos, representa uma alternativa viável para a propagação dessa espécie. Dentre essas técnicas, está a embriogênese somática e, nesse sentido, este estudo objetivou caracterizar a morfogênese in vitro, durante a embriogênese somática, em A. sisalana Perrine. Em todos os experimentos, utilizaram-se bulbilhos como explantes e meio de cultura $\mathrm{MS}^{1} / 2$ acrescido de sacarose $\left(30,0 \mathrm{~g} \mathrm{~L}^{-1}\right)$, solidificado com ágar $\left(7,0 \mathrm{~g} \mathrm{~L}^{-1}\right)$ suplementado com diferentes concentrações de auxinas e citocininas. Os explantes formaram calos com aspectos compactos e semicompactos, evidenciando células embriogênicas que se converteram em embriões somáticos, com o uso de 2,4-D e BAP. Por meio das análises anatômicas, pôde-se observar embriões em estádios globular e torpedo e a não conexão com o calo mãe.

PALAVRAS-CHAVE: Sisal; micropropagação; fibra.

ação do fungo de solo Aspergilus niger. Esse patógeno constitui um ascomiceto, que pode ser veiculado pelo solo, água, vento e ferramentas infectadas, sendo o principal problema fitossanitário da cultura do sisal, no Brasil (Coutinho et al. 2006). Assim, há necessidade de se utilizarem métodos alternativos e eficientes de propagação, que forneçam plantas sadias.

A biotecnologia, em especial as técnicas de cultura de tecidos de plantas, representa uma alternativa viável para a propagação dessa espécie. A micropropagação vem sendo amplamente empregada na produção comercial de plantas, permitindo uma propagação maciça de plantas de interesse econômico, além de proporcionar plantas isentas de doenças

1. Trabalho recebido em ago./2013 e aceito para publicação em jul./2014 ( $n^{\circ}$ registro: PAT 26193).

2. Universidade Estadual de Feira de Santana (UEFS), Departamento de Ciências Biológicas, Feira de Santana, BA, Brasil.

E-mails: asilsante@bol.com.br, adrianarpassos@yahoo.com.br, marilzaagro@hotmail.com, keyllasouzas@yahoo.com.br.

3. Centro de Pesquisas do Cacau, Comissão Executiva do Plano da Lavoura Cacaueira, Ilhéus, BA, Brasil. 
(Sá 2001). A produção de mudas in vitro pode ser obtida via organogênese ou embriogênese somática.

A embriogênese somática é um processo que se assemelha à embriogênese zigótica, porém, se desenvolve a partir de células somáticas, sem a ocorrência da fusão de gametas. Em condições in vitro, os embriões somáticos desenvolvem-se por meio de estágios similares aos observados na embriogênese zigótica, exceto pelo fato de que os embriões somáticos não se tornam dormentes e não são revestidos pelos integumentos e endosperma (Dodeman et al. 1997).

O aprimoramento da técnica de embriogênese somática permitiu o emprego de embriões somáticos na produção de sementes sintéticas e na regeneração de plantas geneticamente modificadas, plantas poliploides e híbridos somáticos, sendo, também, possível a utilização da embriogênese somática na criopreservação de células (Vicent \& Martínez 1998).

A morfogênese in vitro constitui ferramenta importante para promover a reprodução de plantas com características superiores, principalmente para o sisal, no que diz respeito à qualidade da fibra e isenção de enfermidades. Dentro desse contexto, a caracterização desse método permite a execução fidedigna das etapas que permeiam o processo, viabilizando a adequação do método, com base na espécie que se deseja trabalhar, permitindo a obtenção de êxitos na metodologia e retornos para a comunidade científica e sociedade. A técnica apresenta viabilidade de propagação, além da possibilidade de produção de um grande número de mudas, em curto espaço de tempo e com alta sanidade.

Dessa forma, objetivou-se, com o presente trabalho, caracterizar a morfogênese in vitro, durante a embriogênese somática, em Agave sisalana Perrine.

\section{MATERIAL E MÉTODOS}

Os experimentos foram realizados no Laboratório de Cultura de Tecidos Vegetais da Unidade Hortoflorestal da Universidade Estadual de Feira de Santana (UEFS), Laboratório de Micromorfologia Vegetal (UEFS) e Laboratório de Anatomia Vegetal da Universidade Federal do Paraná (UFPR), de 2010 a 2012.

Para a montagem dos experimentos, utilizaram-se, como explantes, bulbilhos de sisal coletados em São Domingos (BA), submetidos ao protocolo de desinfestação desenvolvido por Queiroz et al. (2006). Utilizou-se meio de cultura MS (Murashige \& Skoog
1962), com a metade da concentração de sais (MS 1/2), acrescido de sacarose $\left(30 \mathrm{~g} \mathrm{~L}^{-1}\right)$, solidificado com ágar $\left(7,0 \mathrm{~g} \mathrm{~L}^{-1}\right) . \mathrm{O} \mathrm{pH}$ foi ajustado em 5,8, antes da autoclavagem do meio. Foram distribuídos $15 \mathrm{~mL}$ do meio em tubos de ensaio ( $25 \mathrm{~mm} \times 150 \mathrm{~mm})$.

Para a indução de calos, os explantes foram obtidos por meio de cortes na base dos bulbilhos e inoculados em meio de cultura MS 1/2, acrescido dos reguladores de crescimento 2,4-D (ácido 2,4 diclorofenoxiacético - 0,0 $\mu \mathrm{M} ; 13,6 \mu \mathrm{M} ; 27,2 \mu \mathrm{M}$; $40,8 \mu \mathrm{M}$ ) x BAP (benzilaminopurina - $0,0 \mu \mathrm{M}$; $22,2 \mu \mathrm{M} ; 44,4 \mu \mathrm{M} ; 88,8 \mu \mathrm{M})$ individuais ou combinados entre si.

Após a inoculação, $50 \%$ dos tubos de ensaio foram mantidos em sala de crescimento, com temperatura de $25 \pm 3^{\circ} \mathrm{C}$, sob fotoperíodo de 16 horas e radiação fotossintética ativa de $15 \mu \mathrm{mol} \mathrm{m} \mathrm{m}^{-2} \mathrm{~s}^{-1}$, fornecida por lâmpadas fluorescentes brancas-frias, e o restante cultivado no escuro.

Para cada experimento, utilizou-se o delineamento inteiramente casualizado, em esquema fatorial $2 \times 4 \times 4$ (luz e escuro $x$ concentrações de auxina $\mathrm{x}$ concentrações de citocinina), com cinco repetições por tratamento, sendo cada repetição composta por 2 tubos de ensaio contendo um explante por tubo. Após 30 dias, avaliou-se a percentagem de explantes com calos (explantes responsivos).

Para avaliar o perfil e a viabilidade celular dos calos de $A$. sisalana Per., foram coletadas amostras (50 mg) de calos dos experimentos (indução de calos), as quais foram homogeneizadas com 1,5 mL e $3,0 \mathrm{~mL}$ do reagente CTT (cloreto de 2,3,5 trifeniltetrazólio) $0,6 \%(\mathrm{p} / \mathrm{v})$, preparados em solução tampão fosfato $\mathrm{pH} 7,4$ (Faria et al. 2009) e corantes, como carmim acético e azul de touludina. Posteriormente, as amostras foram enxaguadas com água destilada e montadas as lâminas. As fotomicrografias foram realizadas com câmera digital Olympus acoplada a microscópio de luz transmitida (Zeiss Axioskop 2).

A análise histológica e morfológica do processo embriogênico foi feita em diferentes estádios de desenvolvimento, por meio de microscopia óptica, com registros fotográficos.

As amostras foram coletadas do experimento de indução de calos obtidos do tratamento que continha $13,6 \mu \mathrm{M}$ de $2,4-\mathrm{D}$ e $88,8 \mu \mathrm{M}$ de BAP e consistiram de massas calogênicas contendo diferentes estádios de embriões somáticos.

Para a análise histológica, as amostras foram fixadas em FAA $(0,2 \mathrm{M}, \mathrm{pH} 7,2)$, por 24 horas, 
seguindo-se desidratação em uma série etílica (30\%$95 \%$ ), expondo-se o material por uma hora, em cada série. Para infiltração e emblocamento das amostras, utilizou-se o kit Historesin (Hidroxietilmetacrilato Leica Heidelberg). As amostras permaneceram por 3 a 4 dias em recipiente a vácuo e a polimerização foi realizada à temperatura ambiente. $\mathrm{O}$ material emblocado foi seccionado (5-8 $\mu \mathrm{m}$ de espessura) transversalmente, com o uso de um micrótomo rotativo (Leica RM 2145). Em seguida, as lâminas foram coradas em solução aquosa de azul de toluidina $0,05 \%$ (O’ Brien \& McCully 1981). As fotomicrografias foram realizadas com câmera digital Olympus acoplada a microscópio de luz transmitida (Zeiss Axioskop 2).

Para a maturação e conversão dos embriões somáticos em plantas, foi montado um experimento utilizando-se os calos embriogênicos obtidos nos experimentos anteriores. Aproximadamente $250 \mathrm{mg}$ de massas calogênicas, oriundas do meio que continha $13,6 \mu \mathrm{M}$ de $2,4-\mathrm{D}$ e $88,8 \mu \mathrm{M}$ de BAP, foram transferidas para o meio de cultura MS $1 / 2$ suplementado com BAP $(0,0 \mu \mathrm{M} ; 13,32 \mu \mathrm{M} ; 26,64 \mu \mathrm{M} ; 39,96 \mu \mathrm{M})$, acrescido de $30 \mathrm{~g} \mathrm{~L}^{-1}$ e $40 \mathrm{~g} \mathrm{~L}^{-1}$ de sacarose. Utilizou-se o delineamento inteiramente casualizado, em esquema fatorial $4 \times 2$ (concentrações de BAP $\mathrm{x}$ concentrações de sacarose), totalizando 8 tratamentos com 10 repetições por tratamento, sendo cada repetição composta por 5 tubos de ensaio contendo um explante por tubo.

Após a inoculação, os tubos de ensaio permaneceram em sala de crescimento com temperatura de $25 \pm 3^{\circ} \mathrm{C}$, sob fotoperíodo de 16 horas e radiação fotossintética ativa de $15 \mu \mathrm{mol} \mathrm{m} \mathrm{m}^{-2} \mathrm{~s}^{-1}$. Aproximadamente aos 90 dias após a inoculação, avaliou-se o número médio de embriões convertidos em plantas. Os embriões somáticos foram contados segundo Rodríguez-Sahagún et al. (2011).

A fim de minimizar as perdas da transferência do cultivo in vitro para ex vitro, para aclimatização, as plântulas enraizadas foram transferidas para sacos plásticos de polietileno contendo terra vegetal, cobertas com copos plásticos transparentes $(300 \mathrm{~mL})$ e mantidas em casa-de-vegetação (50\% de luminosidade). As mudas foram irrigadas uma vez ao dia e os copos retirados após 7 dias, quando se considerou a planta totalmente aclimatizada. Avaliou-se, após 30 dias, a taxa de sobrevivência das plantas.

Os dados foram avaliados estatisticamente, mediante análise de variância, testando-se as médias pelo teste Tukey, utilizando-se o programa Sisvar (Ferreira 2011).

\section{RESULTADOS E DISCUSSÃO}

Ocorreu interação tripla (2,4-D x BAP x luz), a qual influenciou, de modo significativo $(\mathrm{p}<0,01)$, a variável percentagem de calos em explantes de bulbilhos de $A$. sisalana Per.

Houve $100 \%$ de formação de calos, quando os explantes foram cultivados nos meios que continham apenas $2,4-\mathrm{D}(13,6 \mu \mathrm{M} ; 27,2 \mu \mathrm{M} ; 40,8 \mu \mathrm{M})$ ou apenas BAP $(88,8 \mu \mathrm{M})$, ou $2,4-\mathrm{D}(27,2 \mu \mathrm{M})$ associado com BAP $(88,8 \mu \mathrm{M})$, na presença de luz (Tabela 1$)$, ou quando foram cultivados nos meios que continham $13,6 \mu \mathrm{M}$ e $40,8 \mu \mathrm{M}$ de 2,4-D com 22,2 $\mu \mathrm{M}$ de BAP ou $40,8 \mu \mathrm{M}$ de $2,4-\mathrm{D}$ e $44,4 \mu \mathrm{M}$ de BAP e $27,2 \mu \mathrm{M}$ de 2,4-D com 88,8 $\mu \mathrm{M}$ de BAP, na ausência de luz (Tabela 2).

Os calos cultivados sob radiação fotossintética apresentaram coloração variando de esverdeada (na ausência da auxina) a esbranquiçada translúcida friável (quando adicionada citocinina), enquanto, na ausência de luz, os calos mostraram-se amarelados, com aspecto semicompacto.

Os explantes de bulbilhos de $A$. sisalana Per. tiveram excelentes respostas para a indução de calos cultivados com os reguladores de crescimento 2,4-D e BAP, demonstrando que os mesmos são cruciais para

Tabela 1. Percentagem de calos em bulbilhos de $A$. sisalana Per., após 30 dias de cultivo em meio MS $1 \frac{1}{2}$ com diferentes concentrações de 2,4-D e BAP, na presença de luz (Feira de Santana, BA, 2012).

\begin{tabular}{cclcc}
\hline \multirow{2}{*}{$2,4-\mathrm{D}(\mu \mathrm{M})$} & \multicolumn{4}{c}{$\mathrm{BAP}(\mu \mathrm{M})$} \\
\cline { 2 - 5 } & 0,0 & 22,2 & 44,4 & 88,8 \\
\hline 0,0 & $10,0 \mathrm{bC}$ & $30,0 \mathrm{aBC}^{\mathrm{b}}$ & $70,0 \mathrm{aAB}$ & $100,0 \mathrm{aA}^{\mathrm{a}}$ \\
13,6 & $100,0 \mathrm{aA}^{\mathrm{a}}$ & $50,0 \mathrm{aB}^{\mathrm{b}}$ & $70,0 \mathrm{aAB}^{\mathrm{a}}$ & $40,0 \mathrm{bB}$ \\
27,2 & $100,0 \mathrm{aA}$ & $60,0 \mathrm{aA}$ & $60,0 \mathrm{aA}$ & $100,0 \mathrm{aA}$ \\
40,8 & $100,0 \mathrm{aA}$ & $40,0 \mathrm{aB}^{\mathrm{b}}$ & $50,0 \mathrm{aB}^{\mathrm{b}}$ & $60,0 \mathrm{abAB}^{\mathrm{a}}$ \\
\hline
\end{tabular}

Médias seguidas pelas mesmas letras minúsculas, na mesma coluna; maiúsculas, na mesma linha; e minúsculas sobrescritas (entre as luminosidades) não diferem, estatisticamente, pelo teste Tukey $(\mathrm{p}<0,05)$. 
Tabela 2. Percentagem de calos em bulbilhos de $A$. sisalana Per., após 30 dias de cultivo em meio MS $1 / 2$ com diferentes concentrações de 2,4-D e de BAP, na ausência de luz (Feira de Santana, BA, 2012).

\begin{tabular}{ccccc}
\hline \multirow{2}{*}{$2,4-\mathrm{D}(\mu \mathrm{M})$} & 0,0 & \multicolumn{3}{c}{$\mathrm{BAP}(\mu \mathrm{M})$} \\
\cline { 2 - 5 } & $20,0 \mathrm{bB}$ & 22,2 & 44,4 & 88,8 \\
\hline 0,0 & $60,0 \mathrm{abAB}$ & $50,0 \mathrm{aA}^{\mathrm{a}}$ & $50,0 \mathrm{bAB}^{\mathrm{b}}$ & $50,0 \mathrm{bB}^{\mathrm{b}}$ \\
13,6 & $80,0 \mathrm{aA}$ & $100,0 \mathrm{aA}^{\mathrm{a}}$ & $20,0 \mathrm{cB}^{\mathrm{b}}$ & $100,0 \mathrm{aA}$ \\
27,2 & $90,0 \mathrm{aA}$ & $70,0 \mathrm{aA}$ & $80,0 \mathrm{abA}$ & $20,0 \mathrm{bB}^{\mathrm{b}}$ \\
40,8 & $100,0 \mathrm{aA}^{\mathrm{a}}$ & $100,0 \mathrm{aA}^{\mathrm{a}}$ & \\
\hline
\end{tabular}

Médias seguidas pelas mesmas letras minúsculas, na mesma coluna; maiúsculas, na mesma linha; e minúsculas sobrescritas (entre as luminosidades) não diferem, estatisticamente, pelo teste Tukey $(\mathrm{p}<0,05)$.

a formação de calos. As auxinas são capazes de iniciar a divisão celular e controlar os processos de crescimento e elongação celular. Segundo George et al. (2008), o 2,4-D tem efeito no metabolismo do RNA, induzindo a transcrição de RNAs mensageiros capazes de codificar proteínas para o crescimento e que podem induzir a proliferação celular desordenada.

Resultados semelhantes foram obtidos por Martínez-Palacios et al. (2003) e Rodríguez-Sahagún et al. (2011), usando os mesmos reguladores em explantes de Agave victoriae e A. tequilana Weber var. Azul, respectivamente. Os calos embriogênicos encontrados neste estudo apresentaram aspectos semicompactos translúcidos e, às vezes, friáveis. Calos semelhantes foram encontrados para outras Agaves (Martínez-Palacios et al. 2003, Nikam et al. 2003).

Foi possível visualizar células embriogênicas em divisão assimétrica periclinal, formando uma célula apical e basal, e célula do suspensor (Figuras 1A e 1B) passando para a fase de pró-embrião (Figuras 1C, $1 \mathrm{D}$ e $1 \mathrm{E})$, de onde, provavelmente, surgiram os embriões somáticos.

Os testes com o corante TTC (2,3,5-cloreto de trifeniltetrazólio) indicaram a presença de enzimas desidrogenases ativas, por meio da coloração vermelha das células (Figuras 1C e 1D) de A. sisalana Per., evidenciando o padrão dessas.

Observações microscópicas afirmaram a individualidade de células dissociadas e divisão ativa assimétrica em suspensão. Observou-se, na região periférica do calo, a presença de massas pró-embriogênicas (Figura 1F) e embriões em diferentes estádios de desenvolvimento, principalmente na fase globular (Figuras 1G e 1L) e torpedo (Figura 1H).

A análise histológica das massas pró-embriogênicas formadas a partir de calos semicompactos de sisal evidenciou intensa divisão das células epidérmicas e das camadas corticais, que se agruparam em fileiras radiais, ocorrendo uma proliferação desor- denada das células parenquimáticas, que empurram a epiderme para o exterior, culminando com sua ruptura. Os feixes vasculares primários (protoxilema), em geral, não se organizaram concentricamente, aparecendo dispersos no parênquima fundamental, nas monocotiledôneas, mostrando, também, a deposição de parede secundária, ocorrendo de forma anelar e helicoidal da parede secundária (Figura 1I). Nas regiões mais internas dos embriões somáticos, observaram-se células vacuoladas com citoplasma denso e núcleos evidentes, bem como pequenos elementos traqueais de xilema (Figura $1 \mathrm{~J}$ ).

Em geral, os explantes de A. sisalana Per. cultivados em meio MS $1 / 2$ acrescido dos reguladores de crescimento responderam, positivamente, ao processo de calogênese. Segundo Guerra et al. (1999), na maioria dos modelos de embriogênese induzidos in vitro, as auxinas, entre elas o 2,4-D, são consideradas as substâncias responsáveis pelo desencadeamento dos processos de desdiferenciação (modelos indiretos) e rediferenciação (modelos diretos), alterando determinação e conferindo novas competências às células responsivas presentes nos explantes. O padrão assimétrico da primeira divisão é uma característica importante para o início do caminho do desenvolvimento embrionário. Duditis et al. (1995) sugeriram que a divisão assimétrica é, provavelmente, consequência da migração da região nuclear central da célula para a periferia.

Estruturas semelhantes foram encontradas por Portillo et al. (2007), em Agave tequilana Weber. Segundo George et al. (2008), a célula apical passa por sucessivas divisões, dando origem ao embrião, enquanto a célula basal, por meio de divisões anticlinais, formará um possível suspensor. Como resultado das análises, foi possível observar apenas a origem unicelular dos embriões somáticos em A. sisalana Per., e esses resultados corroboram os encontrados por Portillo et al. (2007) e Santacruz-Ruvalcaba \& 

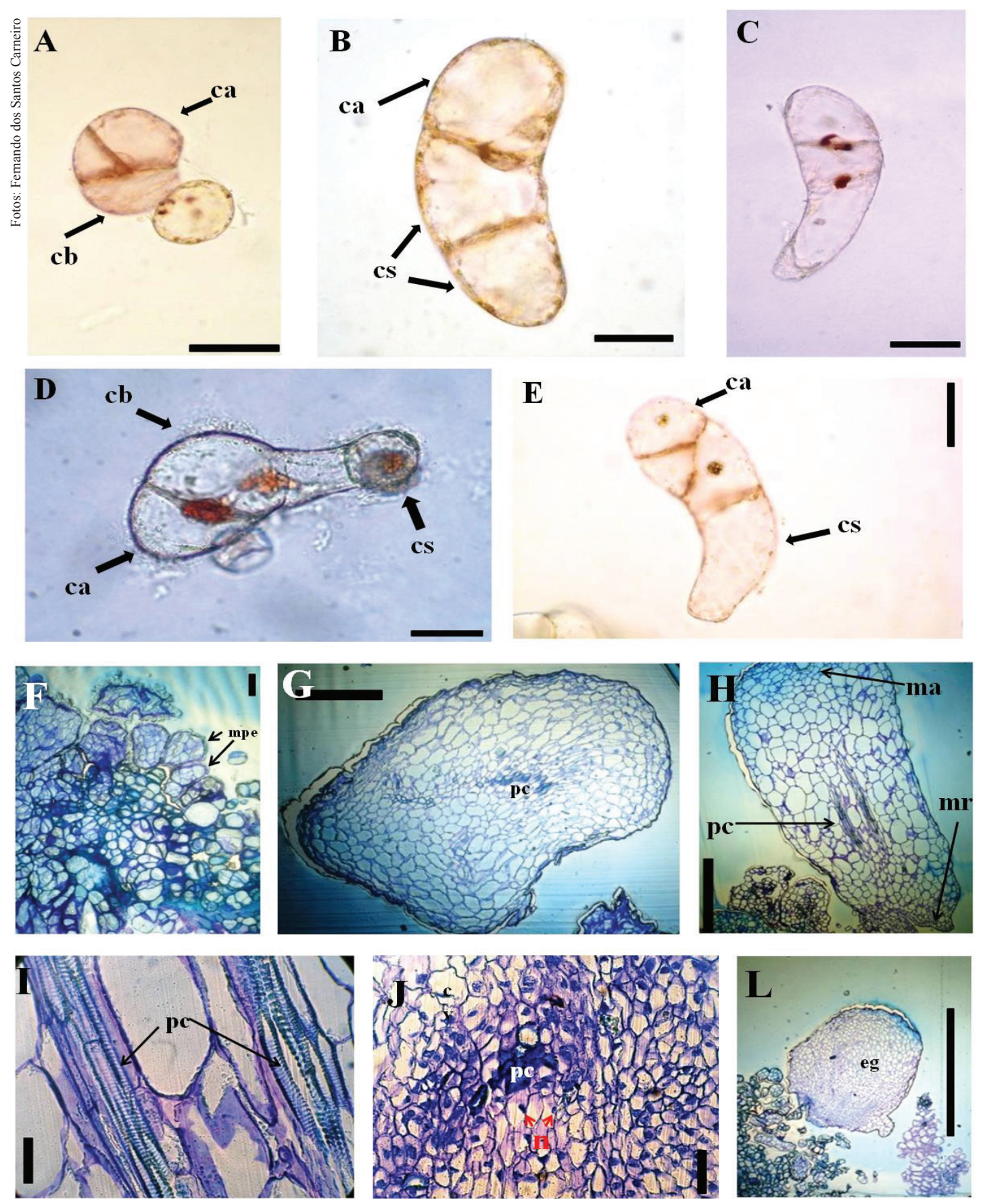

Figura 1. Perfil das células encontradas em calos semicompactos de $A$. sisalana Per., formados a partir da base de bulbilhos, cultivadas em meio de cultura MS 1/2 com diferentes concentrações de auxinas e citocininas. A - estrutura embriogênica polarizada, resultado das primeiras divisões celulares com célula apical e basal. Barra (A) $=20 \mu \mathrm{m}$; B, C e D - estrutura embriogênica polarizada, resultado das primeiras divisões celulares com célula apical e células do suspensor. Barra $(\mathrm{B})=0,05 \mu \mathrm{m}$ e $\mathrm{C}$ e $\mathrm{D}=0,10 \mu \mathrm{m}$; E - pró-embrião com três células e suspensor. Barra $(\mathrm{E})=0,10 \mu \mathrm{m}$. Ca - célula apical, cb - célula basal, cs célula do suspensor; F e G - cortes anatômicos de embriões somáticos de $A$. sisalana Per. F - massas pró-embriogênicas (seta). Barra $(F)=0,2 \mathrm{~mm} ; \mathrm{G}$ - embrião somático em estádio de torpedo e células do pró-câmbio. Barra $(\mathrm{G})=0,75 \mu \mathrm{m}$; $\mathrm{H}$ - embrião somático em estádio de torpedo, mostrando o meristema apical e radicular e feixes vasculares. Barra $(\mathrm{H})=$ $1,0 \mathrm{~mm}$; I - detalhes da deposição dos feixes vasculares e células vasculares. Barra (I) $=30 \mu \mathrm{m}$; J - células vacuoladas evidenciando os núcleos e detalhes do pró-câmbio em embrião, no estádio de torpedo. Barra $(\mathrm{J})=20 \mu \mathrm{m}$; L - embriões somáticos em estádio de torpedo. Barra $(\mathrm{L})=3 \mu \mathrm{m}$. Massa pró-embriogênica: eg - embrião globular, pc - pró-câmbio, ma - meristema apical, mr - meristema radicular, cv - célula vacuolada, n - núcleo. Figuras A, B e E coradas com carmin acético e C e D coradas com 2,3,5-cloreto de trifeniltetrazólio. 
Portillo (2007), trabalhando com A. tequilana Weber, e diferem dos resultados encontrados por Martínez-Palacios et al. (2003), em Agave victoria-reginae T. Moore, e por Tejavathi et al. (2007), em Agave vera-cruz Mill., nos quais os autores observaram origens multicelulares, ao passo que os embriões produzidos por Nikam et al. (2003), em A. sisalana Per., tiveram origens uni e multicelulares.

As análises também não revelaram qualquer ligação vascular entre os embriões somáticos e o calo mãe, confirmando a individualidade de embriões somáticos, conforme descrito por Haccius (1978). Essa característica dos embriões somáticos aliados à sua bipolaridade torna esse modelo morfogenético distinto dos processos de organogênese (Guerra et al. 1999). Os feixes vasculares primários (protoxilema) podem sofrer colapso facilmente, porém, têm a vantagem da extensibilidade (Appezzato-da-Glória \& Carmello-Guerreiro 2003).

Houve efeito altamente significativo $(p<0,01)$, para a dupla interação entre o regulador de crescimento BAP e as concentrações de sacarose presentes no meio de cultura.

Os meios mais eficientes para a conversão dos calos embriogênicos em embriões somáticos foram aqueles onde adicionou-se 39,96 $\mu \mathrm{M}$ de BAP com $30 \mathrm{~g} \mathrm{~L}^{-1}$ de sacarose, ou 13,32 $\mu \mathrm{M}$ de BAP com $40 \mathrm{~g} \mathrm{~L}^{-1}$ de sacarose, sendo possível constatar produção média de 26,16 e 23,33 embriões, respectivamente (Tabela 3). Confirma-se, assim, a importância da utilização de uma fonte de carboidrato no meio de cultura, e a sacarose influencia, diretamente, nos processos de iniciação e diferenciação dos embriões somáticos (Guerra et al. 1999).

Maciel et al. (2003), avaliando o número de embriões formados em calos de C. arabica cv. Obatã, em diferentes concentrações de BAP e sacarose, observaram que a concentração de $30 \mathrm{~g} \mathrm{~L}^{-1}$ de sacarose proporcionou o maior número de embriões, quando associada a $3 \mathrm{mg} \mathrm{L}^{-1}$ de BAP e, quando utilizada a concentração de $15 \mathrm{~g} \mathrm{~L}^{-1}$ de sacarose, houve uma pequena redução no número de embriões.

A sacarose tem sido a fonte de carboidrato mais recomendada na embriogênese somática. Normalmente, a concentração de $3 \%$ de sacarose é satisfatória para a iniciação e diferenciação dos embriões somáticos (Guerra et al. 1999).

Segundo Pereira et al. (2003), o possível aumento no potencial osmótico do meio, ocasionado pela adição de sacarose, influencia tanto no efeito da citocinina (BAP) como, também, na disponibilidade de nutrientes e água, limitando, consequentemente, a difusão desses para o explante e afetando, consequentemente, a quantidade de embriões formados sob baixas concentrações de BAP.

Na figura 2, é possível observar todo o processo de produção de plantas, a partir de células somáticas embriogênicas, em calos de $A$. sisalana Per. Os calos embriogênicos encontrados neste estudo apresentaram aspectos semicompactos translúcidos (Figuras 2A e 2B) e, às vezes, friáveis (Figura 2C). Os primeiros embriões (Figuras $2 \mathrm{D}$ e $2 \mathrm{E}$ ) surgiram a partir de massas nodulares, cerca de 40 dias após a transferência dos calos para o meio de cultura MS 1/2, desprovidos de auxinas ou em baixas concentrações.

Observaram-se embriões passando da fase globular (Figura 2B seta amarela e 2Gb), com coloração esbranquiçada, e, no decorrer do seu desenvolvimento, adquirindo cor verde, passando para o estádio de torpedo, com cotilédone evidente (Figuras $2 \mathrm{Ga}$ e $2 \mathrm{H}$ ). Os embriões seguiram seu desenvolvimento bipolar característico da embriogênese somática, com a formação da parte apical e raízes (Figuras 2H, 2I e $2 \mathrm{~J})$, sendo possível observar o desprendimento dos embriões a partir do calo mãe (Figura 2J).

As plântulas obtidas a partir dos embriões somáticos apresentaram desenvolvimento normal. As plantas de $A$. sisalana Per. demonstraram excelente desenvolvimento, com $100 \%$ de sobrevivência, durante o processo de aclimatização, apresentando as

Tabela 3. Número médio de embriões somáticos (NES) formados a partir de calos embriogênicos $(13,6 \mu \mathrm{M}$ de $2,4-\mathrm{D}$ e $88,8 \mu \mathrm{M}$ de BAP), em bulbilhos de sisal (Agave sisalana Perrine) cultivados na presença de luz, em função de diferentes concentrações de BAP e sacarose (Feira de Santana, BA, 2012).

\begin{tabular}{cllll}
\hline \multirow{2}{*}{ Sacarose $\left(\mathrm{g} \mathrm{L}^{-1}\right)$} & \multicolumn{5}{c}{$\mathrm{BAP}(\mu \mathrm{M})$} \\
\cline { 2 - 5 } & 0,0 & 13,32 & 26,64 & 39,96 \\
\hline 30 & $5,00 \mathrm{bA}$ & $11,16 \mathrm{bB}$ & $11,00 \mathrm{bA}$ & $26,16 \mathrm{aA}$ \\
40 & $1,83 \mathrm{cA}$ & $23,33 \mathrm{aA}$ & $13,50 \mathrm{bA}$ & $16,83 \mathrm{abB}$ \\
\hline
\end{tabular}

Médias seguidas pela mesma letra minúscula, na mesma linha, e maiúscula, na mesma coluna, não diferem, estatisticamente, pelo teste Tukey (p $<0,05$ ). 

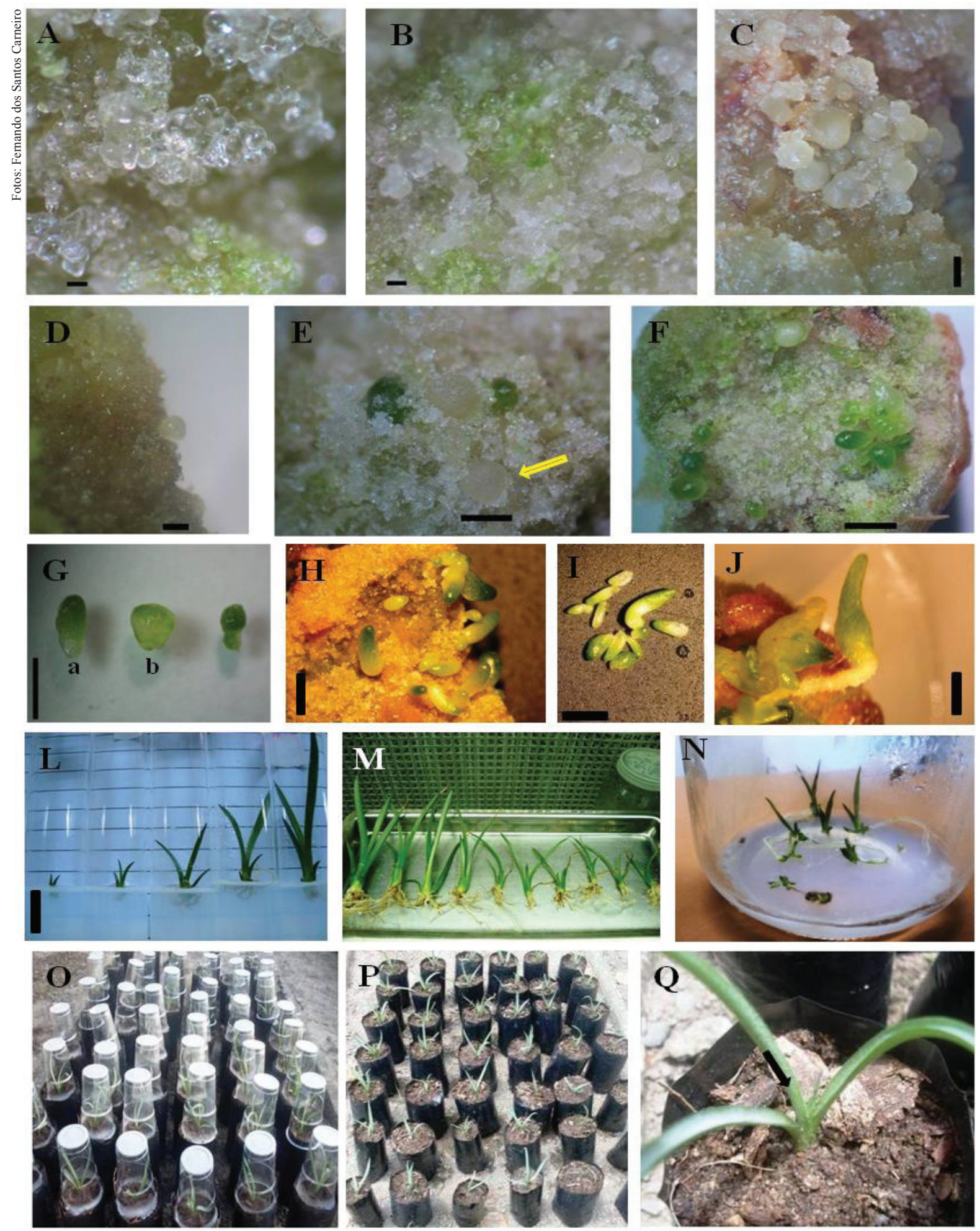

Figura 2. Produção de plantas de A. sisalana Per. via embriogênese somática. A, B e C - calos embriogênicos semicompactos (A e B) e friáveis (C), formados a partir da base de bulbilhos cultivados em meio de cultura MS 1/2 suplementado com 2,4-D $(13,6 \mu \mathrm{M})$ e BAP $(88,8 \mu \mathrm{M})$. Barra $(\mathrm{A}$ e C $)=0,016 \mathrm{~mm}$, Barra $(\mathrm{B})=0,098 \mathrm{~mm}$; D a F - formação de embriões globulares (seta em E). Barra $(D)=1,47 \mathrm{~mm}$, Barra $(E)=1,2 \mathrm{~mm}$ e Barra $(F)=1,2 \mathrm{~mm}$; G a J - embriões somáticos em diferentes estádios de desenvolvimento. G (a) torpedo e (b) globular; J - embriões com raiz. Barra $(\mathrm{G})=1,5 \mathrm{~mm}, \mathrm{Barra}(\mathrm{H})=$ 1,2 mm, Barra $(\mathrm{I})=1,2 \mathrm{~mm}$ e Barra $(\mathrm{J})=1 \mathrm{~cm}$; L - plântulas em meio MS 1/2. Barra $(\mathrm{L})=2 \mathrm{~cm}$; M e N - plântulas antes da aclimatização; O a Q - processo de aclimatização de plantas de A. sisalana Per. 
primeiras folhas após o sétimo dia de transferência (Figura 2Q).

Em experimentos nos quais utilizou-se 2,4-D, nos meios para maturação e conversão dos embriões somáticos (dados não mostrados), os resultados preliminares evidenciaram a influência negativa do regulador de crescimento 2,4-D na conversão e desenvolvimento dos embriões somáticos, em $A$. sisalana Per. As massas pró-embriogênicas que foram expostas ao regulador tiveram seu desenvolvimento reduzido ou comprometido, quando comparadas com outras que não tiveram exposição a esse regulador.

Diversos trabalhos têm relatado a influência do 2,4-D nessa segunda etapa da embriogênese, sendo necessária a redução ou retirada total de qualquer auxina, após a indução inicial da embriogênese (Halperin \& Wetherell 1964, Reinolds \& Murashige 1979, Chée \& Cantliffe 1988, Martínez-Palacios et al. 2003). De acordo com esses autores, isto ocorre porque, após a iniciação, as auxinas, particularmente o 2,4-D, inibem o desenvolvimento subsequente dos embriões. Com base nesses resultados, os experimentos seguintes para conversão dos embriões somáticos foram desprovidos de auxinas.

Tejavathi et al. (2007), trabalhando com Agave vera-cruz Mill., observaram diferenças significativas entre os níveis de sacarose e produziram mais embriões quando os explantes foram cultivados com $4 \mathrm{~g} \mathrm{~L}^{-1}$ de sacarose. O tipo e a concentração do carboidrato são importantes para o desenvolvimento e conversão dos embriões somáticos em plantas.

Além do seu papel como energia e fonte de carbono, os carboidratos estão envolvidos na regulação do potencial osmótico das células vegetais in vitro (Binh et al. 1990). A concentração de sacarose pode influenciar nos processos de iniciação e diferenciação dos embriões somáticos, uma vez que o seu metabolismo, em plantas, é regulado por um grupo de genes (sacarose sintase e sacarose invertase), cujas respostas são moduladas de acordo com a variação da sua concentração (Koch 1996).

De acordo com os resultados obtidos, os reguladores de crescimento 2,4-D e BAP foram eficientes na indução de calos embriogênicos, e a ausência do primeiro foi essencial para a maturação e conversão dos embriões somáticos em $A$. sisalana Per., fato também observado por outros autores, em trabalhos realizados com o gênero Agave (Martínez-Palacios et al. 2003, Portillo et al. 2007, Tejavathi et al. 2007, Rodríguez-Sahagún et al. 2011). Os autores verifi- caram que foram necessárias duas etapas (indução e maturação) para a produção de plantas via embriogênese somática.

Sabe-se que o ambiente in vitro afeta a morfogênese dos explantes, levando, algumas vezes, a consequências indesejáveis para o crescimento e desenvolvimento das culturas, podendo comprometer, principalmente, as estruturas vegetativas que são desejáveis comercialmente, como a presença de fibras vasculares nas folhas do sisal, após o processo de micropropagação (Campostrini \& Otoni 1996).

Em geral, as plantas do gênero Agave apresentam bons resultados, com índice de sobrevivência variável de 95-100\% para Agave tequilana Weber (Portillo et al. 2007), 90\% para Agave victoriae-reginae (Martínez-Palacios et al. 2003) e 100\% para A. sisalana Perrine (Nikam et al. 2003, Rios 2007, Carneiro 2012).

A característica fisiológica das Agaváceas, metabolismo ácido crassuláceae (CAM), influencia, positivamente, nesse processo de aclimatização, uma vez que essas plantas fecham seus estômatos durante o dia, evitando a perda de água, e os abrem durante a noite, absorvendo umidade e permitindo o melhor uso da água (Taiz \& Zeiger 2004).

\section{CONCLUSÕES}

1. A embriogênese somática de $A$. sisalana Per., a partir de bulbilhos, para a retirada de explantes e uso de 2,4D e BAP, mostrou-se eficiente, na produção de plantas.

2. As análises histológicas e anatômicas empregadas mostraram-se eficazes na caracterização dos embriões somáticos, evidenciando o perfil das células encontradas nos calos embriogênicos semicompactos analisados.

\section{REFERÊNCIAS}

APPEZZATO-DA-GLÓRIA, B.; CARMELLOGUERREIRO, S. M. Anatomia vegetal. Viçosa: UFV, 2003.

BINH, L. T. et al. Rapid propagation of agave by in vitro tissue culture. Plant Cell Tissue and Organ Culture, Amsterdam, v. 23, n. 1, p. 67-70, 1990.

CARNEIRO, F. S. Indução de calos e organogênese indireta em sisal (Agave sisalana Perrine).2012.37f. Dissertação (Mestrado em Recursos Genéticos Vegetais) - 
Universidade Estadual de Feira de Santana, Feira de Santana, 2012.

CAMPOSTRINI, E.; OTONI, W. C. Aclimatização de plantas: abordagens recentes. Brasília, DF: EmbrapaCNPH, 1996. (ABCTP notícias, 25).

CHÉE, R.; CANTLIFFE, D. J. Selective enhancement of Ipomoea batatas Poir. embryogenic and non-embryogenic callus growth and production of embryos in liquid culture. Plant Cell, Tissue and Organ Culture, Amsterdam, v. 15, n. 2, p. 149-159, 1988.

COUTINHO, W. M. et al. Bole rot of sisal caused by Aspergillus niger in Brazil. Fitopatologia Brasileira, Brasília, DF, v. 31, n. 6, p. 605-605, 2006.

DODEMAN, V. L.; DUCREUX, G.; KREIS, M. Zygotic embryogenesis versus somatic embryogenesis. Journal of Experimental Botany, Lancaster, v. 48, n. 313, p. 14931509, 1997.

DUDITIS, D. et al. Molecular biology of somatic embryogenesis. In: THORPE, T. A. (Ed.). In vitro embryogenesis in plants. Dordrecht: Kluwer Academic Publishers, 1995. p. 267-308.

EMPRESA BRASILEIRA DE PESQUISA AGROPECUÁRIA (Embrapa). Informações gerais sobre o sisal. 2010. Disponível em: <www.cnpa.embrapa.br>. Acesso em: 25 abr. 2013.

FARIA, C. V. N. et al. Calogênese a partir de segmentos foliares de gabiroba. In: CONGRESSO BRASILEIRO DE FLORICULTURA E PLANTAS ORNAMENTAIS, 17.; CONGRESSO BRASILEIRO DE CULTURA DE TECIDOS DE PLANTAS, 4., 2009, Aracaju. Anais... Aracaju: SBFPO/ABCTP, 2009. 1 CD-ROM.

FERREIRA, D. F. Sisvar: a computer statistical analysis system. Ciência e Agrotecnologia, Lavras, v. 35, n. 6, p. 1039-1042, 2011.

GEORGE, E. F.; HALL, M. A.; KLERK, G. J. Plant propagation by tissue culture. 3. ed. Dordrech: Springer, 2008.

GUERRA, M. P.; TORRES, A. C.; TEIXEIRA, J. B. Embriogênese somática e sementes sintéticas. In: TORRES, A. C.; CALDAS, L. S.; BUSO, J. A. (Eds.). Culturas de tecidos e transformação genética de plantas. Brasília, DF: Embrapa-CBAB, 1999. p. 533-568.

HACCIUS, B. Questions of unicellular origin of nonzygotic embryos in callus cultures. Phytomorphology, New Delhi, v. 28, n. 1, p. 74-81, 1978.

HALPERIN, W.; WETHERELL, D. F. Adventive embryony in tissue cultures of the wild carrot, Daucus carota. American Journal of Botany, Columbus, v. 51, n. 3, p. 274-283, 1964.
KOCH, K. E. Carbohydrate-modulated gene expression in plants. Plant Physiology and Plant Molecular Biology, Gainesville, v. 47, n. 5, p. 509-540, 1996.

MACIEL, M. de N. M. et al. Classificação ecológica das espécies arbóreas. Revista Acadêmica: Ciências Agrárias e Ambiental, Curitiba, v. 1, n. 2, p. 69-78, 2003.

MARTÍNEZ-PALACIOS, A. et al. Somatic embryogenesis and organogenesis of Agave victoriae-reginae: considerations for its conservation. Plant Cell, Tissue and Organ Culture, Amsterdam, v. 74, n. 2, p. 135-142, 2003.

MURASHIGE, T.; SKOOG, F. A revised medium for rapid growth and bioassays with tobacco tissue cultures. Physiology Plantarum, Oxford, v. 15, n. 3, p. 473-497, 1962.

NIKAM, T. D.; BANSUDE, K. C.; ANEESH, K. C. Somatic embryogenesis in sisal (Agave sisalana Perr. Ex. Engelm). Plant Cell Reports, Heidelberg, v. 22, n. 3, p. 188-194, 2003.

O'BRIEN, T. P.; MCCULLY, M. E. The study of plant structure principles and selected methods. Melbourne: Termacarphi, 1981.

PEREIRA, I. M. et al. Use-history effects on structure and flora of Caatinga. Biotropica, Lawrence, v. 35, n. 2, p. 154-165, 2003.

PORTILLO, L. et al. Somatic embryogenesis in Agave tequilana Weber cultivar azul. In Vitro Cellular \& Developmental Biology Plant, Washington, DC, v. 43, n. 6, p. 569-575, 2007.

QUEIROZ, S. R. O. D. et al. Estabelecimento in vitro de sisal (Agave sisalana Perrine): I. Controle da contaminação e da oxidação. Magistra, Cruz das Almas, v. 18, n. 3, p. 130-139, 2006.

REYNOLDS, J. F.; MURASHIGE, T. Asexual embryogenesis in callus cultures of palms. In Vitro, Wallingford, v. 15, n. 5, p. 383-387, 1979.

RIOS, A. P. S. Estabelecimento, organogênese direta e aclimatização de sisal (Agave sisalana Perrine). 105 f. 2007. Dissertação (Mestrado em Biotecnologia) - Universidade Estadual de Feira de Santana, Feira de Santana, 2007.

RODRÍGUEZ-SAHAGÚN, A. et al. Effect of light quality and culture medium on somatic embryogenesis of Agave tequilana Weber var. Azul. Plant Cell, Tissue and Organ Culture, Amsterdam, v. 104, n. 2, p. 271-275, 2011.

SÁ, M. E. L. Propagação in vitro de diferentes genótipos de abacaxizeiro por meio de seccionamento de plântulas. Revista Brasileira de Fruticultura, Jaboticabal, v. 23, n. 1, p. 17-20, 2001. 
SANTACRUZ-RUVALCABA, F.; PORTILLO, L. Thin cell suspension layer as a new methodology for somatic embryogenesis in Agave tequilana Weber cultivar azul. Industrial Crops and Products, Amsterdam, v. 29, n. 2-3, p. 609-614, 2009.

TAIZ, L.; ZEIGER, E. Fisiologia vegetal. 3. ed. Porto Alegre: Artmed, 2004.
TEJAVATHI, D. H. et al. Induction of somatic embryos from cultures of Agave vera-cruz Mill. In Vitro Cellular \& Developmental Biology Plant, Washington, DC, v. 43, n. 5, p. 423-428, 2007.

VICENT, C. M.; MARTÍNEZ, F. X. The potential uses of somatic embryogenesis in agroforestry are not limited to synthetic seed technology. Revista Brasileira de Fisiologia Vegetal, Campinas, v. 10, n. 1, p. 1-12, 1998. 